\title{
Zarządzanie przez kluczowe wartości - zarys koncepcji
}

https://doi.org/10.33141/po.2005.02.02

Przegląd Organizacji, Nr 2 (781), 2005, ss. 12-14 www.przegladorganizacji.pl

\section{Pojęcie kluczowych wartości}

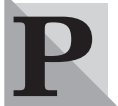

rzyjmuje się, że wartość to „[...] wytwór odczuć, przeświadczeń lub przekonań jakiegoś podmiotu: jednostki ludzkiej, grupy społecznej, społeczności lokalnej, narodowej i innej, wspólnoty kulturowej lub społeczeństwa globalnego o tym, co w rzeczywistości przyrodniczej i psychospołecznokulturowej jest pozytywnie oceniane i uznawane za godne pożądania i dążeń" [L.J. Krzyżanowski, 1999, s. 205]. W tym rozumieniu wartości:

- są dziełem myśli lub ludzkich odczuć; nie są więc czymś samym w sobie, całkowicie niezależnym od naszego odniesienia do nich;

- mają wymiar normatywny, tj. powinnościowy;

- wpływaja na działania ludzi i stanowia kryteria wyboru celów indywidualnych i zbiorowych [L. Krzyżanowski, 1999].

Na potrzeby niniejszego artykułu szczególnie przydatny jest podział wartości na kluczowe i pośrednie. Te pierwsze są stanami docelowymi, godnymi zarówno indywidualnych, jak i społecznych dążeń. Drugie natomiast mają instrumentalny charakter, są niejako środkami służącymi do realizacji wartości kluczowych. Wynika stąd, że wartości kluczowe są nadrzędne wobec pośrednich [L.J. Krzyżanowski, 1999].

Przykładami kluczowych wartości przedsiębiorstwa mogą być: ludzie jako źródło naszej siły, podejmowane przez nich wielkie wyzwania i ryzyko oraz ich indywidualne inicjatywy [J.C. Collins, J.I. Porras, 2003]. Jako wartości pośrednie można m. in. wymienić: fachowość, osobistą odwagę i identyfikację z zawodem.

Należy podkreślić, że kluczowe wartości są niezmienne, nie można od nich odstępować w realizacji konkretnych zamierzeń, przedsięwzięć i zadań. Mają one nadrzędny charakter w stosunku do wartości, o których jest mowa np. w modelu kultury organizacji E. Scheina [E. Schein, 1984].

Główną funkcją kluczowych wartości przedsiębiorstwa jest sprzyjanie osadzaniu go na trwale w rzeczywistości. W szczególności owe wartości przyczyniają się do przetrwania przedsiębiorstwa w zmieniającym się otoczeniu i budowania w nim ładu. Są kamieniem węgielnym kultury organizacyjnej, struktury organizacyjnej czy strategii.

\section{Procedura zarządzania przez kluczowe wartości} polega na realizacji kilku etapów. Są nimi: - powołanie zespołu roboczego,
- sformułowanie kluczowych wartości,

- propagowanie ich,

- „nasycenie” kluczowymi wartościami działań związanych z zarządzaniem zasobami ludzkimi,

- eliminowanie rozbieżności między kluczowymi wartościami i zachowaniami pracowników.

Jak podkreśla P.M. Lencioni, szefowie firm powierzają zazwyczaj kształtowanie zbioru wartości działowi kadr, który uruchamia badania i organizuje wiele zebrań, aby zgromadzić niezbędne informacje i doprowadzić do zbudowania konsensusu [P.M. Lencioni, 2004]. Budowanie zbioru wartości tą drogą nie jest jednak, zdaniem przywołanego autora, właściwym rozwiązaniem. „Pytanie pracowników, jakie wartości powinny obowiązywać w firmie, to wyjątkowo zły pomysł, i to z dwóch powodów. Po pierwsze, bierze pod uwagę zdanie także tych osób, dla których firma wcale nie jest najważniejsza. Po drugie, prowadzi to do powstania fałszywego wrażenia, że wszystkie głosy są równie istotne [P.M. Lencioni, 2004, s. 124].

Wydaje się, że najlepszym rozwiązaniem jest powierzenie sformułowania kluczowych wartości niewielkiemu zespołowi, złożonemu z menedżerów najwyższych szczebli zarządzania oraz założycieli firmy, jeżeli oczywiście ciągle jeszcze w niej pracują [P.M. Lencioni, 2004]. Udział menedżerów można uzasadnić tym, że kluczowe wartości niewątpliwie ułatwiaja wykonywanie działań zarządczych, przeto nie tylko mogą, ale wręcz muszą mieć wpływ na to, jakie wartości będą regulowały ich zachowania. Współudział założycieli jest pożądany natomiast przede wszystkim dlatego, że ich zamierzenia, jak ujawniają badania J.C. Collinsa i J.I. Porrasa, sa często wzorcem działania przedsiębiorstw osiągających w długim okresie ponadprzeciętne wyniki [J.C. Collins, J.I. Porras, 2003].

Celem zespołu roboczego jest opracowanie zbioru kluczowych wartości na podstawie tzw. nadrzędnego celu przedsiębiorstwa. Cel ten jest fundamentalnąjego przyczyna, wyrażającą znaczenie, jakie ludzie przypisują działaniu firmy. Oddaje niejako jej duszę i jest niezmienny (tabela).

Jeśli nadrzędny cel nie został ustalony, zespół roboczy powinien się tym zająć, posługując się np. metodą „pięć razy dlaczego”. Zadając pięciokrotnie pytanie - dlaczego ważne jest, że wytwarzany jest produkt $\mathrm{X}$, albo też świadczona jest usługa $\mathrm{X}$ - dość szybko i skutecznie, zdaniem J.C. Collinsa i J.I. Porrasa, można dotrzeć do fundamentalnych przyczyn istnienia firmy [J.C. Collins, J.I. Porras, 2003].

Kluczowe wartości muszą być spójne z nadrzędnym celem, są niejako jego dopełnieniem. Razem stanowią nadrzędną ideologię, której nie można mylić z kluczowymi kompetencjami przedsiębiorstwa. Sa 
Tab. Przykłady nadrzędnych celów

\begin{tabular}{|l|l|}
\hline \multicolumn{1}{|c|}{ Firma } & \multicolumn{1}{c|}{ Nadrzędny cel } \\
\hline $3 \mathrm{M}$ & Rozwiązywać w sposób innowacyjny istniejące problemy \\
\hline McKinsey & Pomóc w odnoszeniu sukcesów korporacjom i rządom \\
\hline Merck & Zachowywać i poprawiać ludzkie życie \\
\hline Nike & Doświadczyć emocji związanych z konkurowaniem, zwyciężaniem i miażdżeniem przeciwników \\
\hline Sony & Doświadczać radości, jaką daje ulepszanie technologii i stosowanie jej dla dobra ludzkości \\
\hline
\end{tabular}

Źródło: na podstawie pracy [J.C. COLLINS, J.I. PORRAS, 2003, s. 237].

one bowiem jego zdolnościami, tymczasem nadrzędna ideologia odpowiada na pytanie, dlaczego firma istnieje [J.C. Collins, J.I. Porras, 2003].

Opracowując zbiór kluczowych wartości zespół musi skupić się na uchwyceniu ich sedna. Niezbędne jest osiągnięcie przez członków zespołu pełnego zrozumienia, a także odpowiedniego sformułowania kluczowych wartości. Jeżeli mają być autentyczne, nie mogą brzmieć jak tekst z okolicznościowej karty [P.M. Lencioni, 2004]. Nie może też być żadnych niedomówień, ponieważ wszelkie niejasności z reguły dezinformują pracowników. Im są prostsze, bardziej bezpośrednie i łatwiejsze do zrozumienia, tym lepiej [K. Blanchard, M. O’Connor, 1998].

Ze sformułowaniem dobrego zbioru kluczowych wartości nie wolno się spieszyć. Chodzi przecież nie o to, by szybko uzgodnić wspólne stanowisko, którego będzie się później żałować, lecz o wypracowanie wartości, które można porównać do Dekalogu czy prawd zawartych w amerykańskiej Deklaracji Niepodległości. Członkowie zespołu muszą pracować przez dłuższy okres, zastanawiając się, czy pojawiające się rozwiązania odpowiadaja realiom ich firmy [P.M. Lencioni, 2004].

Załóżmy, że zespół zdołał sformułować właściwy zbiór kluczowych wartości. Następnym krokiem jest ich propagowanie. Zajmować się tym powinni nie tylko członkowie zespołu, ale także wszyscy ci, którzy się z nim identyfikują. Moga to być zarówno menedżerowie różnych szczebli, jak i szeregowi pracownicy, zainteresowani polepszaniem wyników firmy i zapewnieniem jej powodzenia w przyszłości.

Jedną z metod propagowania kluczowych wartości jest ich drukowanie gdzie tylko się da - na plakatach, ulotkach, wizytówkach, firmowych koszulkach, nawet kubkach do kawy. Można też, jak to się dzieje w firmie Wal-Mart, pieniężnie nagradzać pracowników postępujących w zgodzie z ustalonymi wartościami, a nawet manifestacyjnie wyrażać im podziw [P.M. Lencioni, 2004]. Najskuteczniejszą jednak metoda wydaje się być ta, którą stosuje amerykańska sieć domów towarowych Nordstrom. Zamiast precyzyjnego instruowania pracowników w zakresie właściwej obsługi klientów, opowiada się im o wysiłkach, jakie podjęli niektórzy zatrudnieni, aby zadowolić klientów. Takie ciagle powtarzane opowieści, jak np. o sprzedawcy, który przyjął bez słowa zwrot zakupionego kilka lat wcześniej swetra, przyczyniają się do utwierdzenia wśród zatrudnionych przekonania o przynależności do wyjątkowej organizacji [P.M. Lencioni, 2004].
Propagowanie kluczowych wartości powinno być, co należy podkreślić, procesem ciaggłym. Pracownicy ponoć dopóty nie wierzą w przekaz, dopóki nie usłyszą go siedem razy. Ze względu na to, że zagadnieniom wartości często towarzyszy klimat cynizmu, dobrze jest, kiedy zwłaszcza przełożeni odwołują się do nich przy każdej nadarzającej się okazji [P.M. Lencioni, 2004]. Pracownicy muszą być przekonani, że tak naprawdę prawdziwym „szefem” firmy są jej kluczowe wartości.

Jeżeli chcemy, aby kluczowe wartości miały realny wpływ na funkcjonowanie i rozwój przedsiębiorstwa, należy nimi „nasycić” działania związane z zarządzaniem zasobami ludzkimi. Procedury rekrutacji, selekcji, programy i plany szkoleniowe, zasady wynagradzania i awansowania musza być tak zaprojektowane, aby pracownicy nie mieli wątpliwości, jakie wartości mają kluczowy charakter.

Przykładem firmy, która potrafi skutecznie wtapiać kluczowe wartości - m.in. nastawienie na człowieka, a nie na maszynę oraz polepszanie jakości poprzez innowacje - w zarzadzanie zasobami ludzkimi jest Volkswagen Motor Polska Sp. z o.o. Proces ten rozpoczyna etap rekrutacji majacy na celu pozyskanie takich kandydatów do pracy, którzy:

- przejawiają inicjatywę w pracy,

- potrafią pracować w grupie i rozwiązywać konflikty,

- łatwo nawiązuja kontakty,

- są odpowiedzialni,

- chcą i mogą ciągle uczyć się.

Selekcja odbywa się często za pomocą procedury ośrodka ocen. Kandydaci pracują w kilkuosobowych zespołach (budując określoną konstrukcję, np. model domu), a ich poczynania dokładnie obserwuje komisja, oceniajacca nie tyle rezultat wspólnej pracy, ile przede wszystkim sposoby działania poszczególnych osób. Jednym z pięciu kryteriów oceny kandydatów jest, podkreślić należy, inicjatywa w działaniu.

Istotnym elementem systemu zarządzania potencjałem społecznym w tej firmie jest plan rozwoju osobistego, będący podstawą budowania przyszłej kadry kierowniczej, od której wymaga się m.in. ciągłego wprowadzania innowacyjnych idei. Obejmuje on różne szkolenia, kończące się egzaminem kwalifikującym pracownika do jednej z czterech nasteppujacych grup: - osoby przygotowane do pełnienia funkcji zarządczych w koncernie VW AG,

- osoby spełniajace wymagania do pełnienia funkcji zarządczych w VW Motor Polska Sp. z o.o., 
- osoby mające pewne braki w zakresie umiejętności menedżerskich,

- osoby nie nadające się do pełnienia funkcji zarządczych.

Uzyskanie najniższej oceny nie pozbawia pracownika szansy na pełnienie w przyszłości funkcji zarządczych, ponieważ po pewnym czasie może ponownie uczestniczyć w szkoleniach i zdawać egzamin sprawdzający zdobytą wiedzę i umiejętności. Z kolei pracownicy zakwalifikowani do dwóch pierwszych grup nie obejmują stanowisk kierowniczych natychmiast, lecz stanowią tzw. rezerwę kierowniczą [M. Hopej, 2004].

Zarządzanie przez kluczowe wartości polega wreszcie na eliminowaniu niezgodności między zachowaniami pracowników i wartościami. Wymaga ono ze strony wszystkich przełożonych odpowiedniego „obchodzenia się z ludźmi", tj. m.in.:

- przestrzegania złotej reguły,

- niewtrącania się do wszystkiego,

- ciagłego wsłuchiwania się w opinie, uwagi i propozycje podwładnych,

- stworzenia takiej atmosfery pracy, w której nie karze się niepowodzeń, lecz traktuje się je jako pożyteczne doświadczenia,

- dodawania podwładnym odwagi [M. Hopej, 2004].

Eliminowanie niezgodności wymaga również opracowania wskaźników pomiaru zachowań organizacyjnych. Ściślej mówiąc, niezbędne jest zaprojektowanie takich wskaźników, za pomocą których będzie można ustalić stopień, w jakim zachowania pracowników sa zgodne (względnie sprzeczne) z wzorcowymi, wynikającymi z kluczowych wartości. Chodzi bowiem o to, by nawet najmniejsze odchylenia od wzorca były szybko identyfikowane i eliminowane.

Doświadczenia wielu organizacji wskazuja, że to co jest mierzone, jest również traktowane za istotne. Wskaźniki pomiaru wpływają zatem zarówno na to „[...] co ludzie robią, jak i na to, co zauważaja, a co ignorują. W efekcie wszyscy wiedzą, że to, co podlega pomiarowi, jest zwykle realizowane, natomiast to, co nie jest mierzone, często bywa traktowane jako nieistotne" [J. Pfeffer, R.I. Sutton, 2002, s. 129].

\section{Zagrożenia i korzyści zarządzania przez kluczowe wartości}

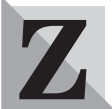

astosowanie zarządzania przez kluczowe wartości wiąże się z pewnymi zagrożeniami. Do najbardziej istotnych zaliczyć należy:

- wspomniany wcześniej, otaczający kwestię wartości klimat cynizmu, który nie pozwala na uzyskanie stuprocentowej pewności, co do osiagania oczekiwanych wyników;

- konieczność pokonywania oporów wobec prób narzucenia niektórym pracownikom określonych wartości;

- trudności w opracowaniu wskaźników pomiaru zachowań pracowników; nie ma i nie może być jednego, uniwersalnego zestawu wskaźników, dlatego każda firma musi samodzielnie je zaprojektować tak, by odzwierciedlały one nadrzędny cel i własny, specyficzny zbiór kluczowych wartości;
- trudności postępowania zgodnego z kluczowymi wartościami; zdecydowanie trudniej jest niezłomnie stać na straży sformułowanych wartości niż stosować np. zasady politycznej poprawności [P.M. Lencioni, 2004].

Zaprezentowana koncepcja zarządzania ma jednak istotne zalety. Zaliczyć do nich można przede wszystkim to, że kluczowe wartości:

- ułatwiaja pracownikom zrozumienie tego, dzięki czemu przedsiębiorstwo działa i ma działać w przyszłości;

- sprzyjaja zachowaniu ciągłości działania przedsiębiorstwa;

- pełnią rolę spoiwa łączącego przedsiębiorstwo w całość;

- nie tylko są propagowane, ale także wdrażane w codziennym działaniu [M. Hopej, 2004].

\section{Podsumowanie}

7 arządzanie przez kluczowe wartości nie tylko jest możliwe, ale również chyba konieczne. Odpowiednio skonstruowany i konsekwentnie wdrażany zbiór kluczowych wartości może wyróżniać przedsiębiorstwo wśród konkurentów, kształtując jego tożsamość i jednocząc pracowników. „Nasycenie” takimi wartościami wszelkich realizowanych procesów powoduje, że ludzie osiągnać mogą wspaniałe rezultaty, a przedsiębiorstwo nie będzie mówiąc językiem sportowym - sprinterem, lecz maratończykiem.

Zarysowana w artykule koncepcja jest jednak dużym wyzwaniem. Zarządzanie przez kluczowe wartości wymaga nieustannej czujności i nigdy się nie kończy. Jeżeli brak jest szczerych chęci ponoszenia wszelkich skutków, w tym również bolesnych, takiego zarządzania, w ogóle nie należy podejmować trudu choćby tylko tworzenia zbioru kluczowych wartości.

dr hab. inż. Marian Hopej prof. Politechniki Wrocławskiej Instytut Organizacji i Zarządzania

\section{BIBLIOGRAFIA}

[1] BLANCHARD K., O'CONNOR M., Zarzqdzanie przez wartości, Studio EMKA, Warszawa 1998.

[2] COLLINS J.C., PORRAS J.I., Wizjonerskie organizacje. Praktyki zarzadzania najlepszych firm, SPM Project, 2003.

[3] HOPEJ M., Megawartości przedsiębiorstwa a jego innowacyjność, [w:] J. SKALIK (red.), Zmiana warunkiem sukcesu. Zmiana a innowacyjność organizacji, Wydawnictwo Akademii Ekonomicznej im. Oskara Langego we Wrocławiu, Wrocław 2004.

[4] KRZYŻANOWSKI L., O podstawach kierowania organizacjami inaczej, Wydawnictwo Naukowe PWN, Warszawa 1999.

[5] LENCIONI P.M., Niech wartości naprawdę coś znacza, „Harvard Business Review Polska”, maj 2004.

[6] PFEFFER J., SUTTON R.I., Wiedza $w$ dziataniu, Oficyna Ekonomiczna, Kraków 2002.

[7] SCHEIN E., Coming to a New Awareness of Organizational Culture, „Sloan Management Review” 1984, nr 25. 